Penelitian

\title{
Morfologi Kelenjar Anal Musang Luak Jantan (Paradoxurus hermaphroditus)
}

\author{
Morphology of Anal Gland of Common Palm Civet Male (Paradoxurus hermaphroditus)
}

\author{
Inggrid Trinidad Maha", ${ }^{1,2}$ I Ketut Mudite Adnyane³, Savitri Novelina ${ }^{3 *}$ \\ 'Jurusan Anatomi bagian Anatomi, Fisiologi dan Biokimia, Fakultas Kedokteran Hewan, Universitas Nusa Cendana \\ ${ }^{2}$ Program Studi Anatomi Perkembangan Hewan, Sekolah Pascasarjana, Institut Pertanian Bogor \\ ${ }^{3}$ Divisi Anatomi Histologi dan Embriologi, Departemen Anatomi Fisiologi dan Farmakologi, Fakultas Kedokteran Hewan, \\ Institut Pertanian Bogor \\ *Penulis untuk korespondensi: savitri.novelina@gmail.com \\ Diterima 22 Januari 2018, Disetujui 1 Desember 2018
}

\begin{abstract}
ABSTRAK
Penelitian ini bertujuan untuk mempelajari karakteristik morfologi kelenjar anal musang luak jantan secara makroskopis maupun mikroskopis. Organ kelenjar anal dari satu ekor musang luak (Paradoxurus hermaphroditus) jantan digunakan dalam penelitian ini. Pengamatan makroskopis meliputi pengamatan topografi, bentuk dan ukuran kelenjar anal. Pengamatan secara mikroskopis dilakukan dengan pembuatan preparat histologi menggunakan pewarnaan hematoxilin - oosin (HE) untuk mengamati bentuk sel kelenjar anal. Musang luak jantan memiliki sepasang kelenjar anal yang berbentuk bulat terletak di bagian ventrolateral anus. Daerah kanal anal musang luak terbagi atas tiga daerah yaitu zona kutaneus, zona intermediate dan zona kolumnar Masing-masing kelenjar anal memiliki saluran eksretorius sekretori yang terletak dorsolateral di bagian zona kutaneus anal kanal. Pengamatan mikroskopis tampak kelenjar sebaceous dan kelenjar keringat apokrin di dinding kantung anal. Hasil sekreta kelenjar anal terkumpul dalam sebuah kantung anal yang akan bermuara di anal kanal.
\end{abstract}

Kata kunci: musang luwak, kelenjar anal, kelenjar sebaceous, kelenjar keringat apokrin

\begin{abstract}
This research was aimed to describe the morphology of anal gland of common palm civet male. One male of common palm civet was used in this research which observed macroscopic and microscopic. The result showed that common palm civet have a pair of anal gland which hasshaped like ball and located in the anal sacs wall's in the ventrolateral of anus.Each anal gland has a ductus excretorius dorsolaterally in the cutaneous zone of anal canal. Microscopic observation showed a well developed sebaceous gland and apocrine sweat gland in the wall of anal sac. Sebaceous and apocrine glands were excreted their product into main ductus to the anal canal.
\end{abstract}

Keywords: common palm civet, anal gland, sebaceous gland, apocrine sweat gland 


\section{PENDAHULUAN}

Musang luak (Paradoxurus hermaphroditus) dikenal oleh masyarakat karena menghasilkan biji kopi yang dikenal dengan kopi luak. Menurut konsumen penikmat kopi, kopi luak mempunyai cita rasa yang enak dan kadar asam yang rendah sehingga aman untuk lambung. Indonesia merupakan salah satu negara produsen kopi luak, oleh karena itu kopi luak mempunyai nilai ekonomis yang tinggi dan menjadi komoditas ekspor di Indonesia. Dengan meningkatnya permintaan kopi luak, maka budidaya musang luak sudah mulai banyak di kembangkan di Indonesia.

Musang luak termasuk ke dalam famili Viverridae. Di Indonesia terdapat sembilan famili Viverridae dan sepuluh spesies yang tersebar di beberapa wilayah. Diantara 10 spesies terdapat 5 spesies yang berada di pulau Jawa antara lain: binturong muntu (Arctictis binturong), musang akar (Arctogalida trivirgata), musang luak (Paradoxurus hermaphroditus), linsang linsang (Prionodon linsang), dan musang rase (Viverricula indica) (Suyanto, 2002) Hewan yang termasuk famili Viverridae ini dicirikan memiliki kaki kecil dan pendek, ekor panjang dan memiliki kelenjar penanda (Grzimek et al., 2004).

International Union for conservation of Nature (IUCN) memasukkan musang luak kedalam daftar least concern, yang berarti bila tidak diperhatikan maka populasinya akan menurun drastis. Data populasi musang luak sejauh ini belum pernah dilaporkan.Pola perkawinan musang luak masih terjadi secara alami, para peternak musang menemukan anakan musang di alam, kemudian dipelihara hingga dewasa (Panggabean., 2011). Status musang luak di Indonesia tidak dilindungi namun demikian perdagangan komersial dibatasi oleh system kuota tahunan oleh Lembaga Ilmu Pengetahuan Indonesia (LIPI), sejak 5 tahun terakhir kuota dibatasi sebanyak 250-300 ekor yang terbagi di propinsi Sumatera Utara, Lampung, Jawa Barat, Jawa Tengah dan Nusa Tenggara Barat (Nijman et al., 2014).

Penamaan Paradoxurus hermaphroditus berdasarkan adanya kelenjar anal pada musang jantan maupun betina terletak di bawah ekor yang menyerupai testis (Baker \& Kelvin 2008). Kelenjar ini memproduksi sekreta yang berperan sebagai aroma penanda, sekreta ini mempunyai aroma seperti bau daun pandan dan aroma ini dapat tercium di sekitar tempat tinggal musang luak. Penelitian Rozhnov \& Rozhnov (2003) menunjukkan bahwa sekreta dari kelenjar anal musang dapat dijadikan sebagai media komunikasi diantara mereka.
Hasil penelitian Hong Fa et al. (1995) menyatakan bahwa musang lebih aktif mengeluarkan aroma penanda ini pada saat birahi. Stimulus dari aroma penanda ini menjadi penentu dalam memilih pasangan. Musang luak jantan lebih aktif mengeluarkan aroma untuk memberi sinyal kepada hewan betina dan menandai daerah teritori.

Dalam usaha penangkaran musang luak, diperlukan data-data mengenai biologi dan fisiologi organ reproduksi musang luak. Penelitan mengenai morfologi organ reproduksi musang luak yang sudah dilaporkan adalah organ reproduksi jantan (Putra, 2012) dan organ reproduksi betina (Apriliani, 2012). Penelitian mengenai kelenjar anal musang luak jantan belum pernah di laporkan, namun penelitian serupa pada hewan lain sudah dilaporkan antara lain pada anjing (Tsukise et al., 2000), kucing (Maheret al., 2015), harimau (Hashimoto et al., 1963). Morfologi kelenjar anal musang luak jantan menarik untuk diteliti karena kelenjar anal ini berkaitan erat dengan komunikasi reproduksi dan data mengenai kelenjar anal pada musang luak ini masih sangat terbatas. Penelitian ini diharapkan dapat digunakan sebagai informasi data dasar tentang anatomi dalam bidang satwa liar maupun dalam budidaya musang luak.

\section{BAHAN DAN METODE}

Penelitian ini menggunakan organ kelenjar anal dari satu ekor musang luak (Paradoxurus hermaphroditus) jantan dengan bobot tubuh $4 \mathrm{~kg}$ yang berasal dari hasil tangkapan masyarakat. Hewan di anastesi menggunakan xylazine dan ketamin dengan dosis masing-masing $2 \mathrm{mg} / \mathrm{kg} B B$ dan $10 \mathrm{mg} / \mathrm{kg}$ BB. Musang dalam keadaan terbius diperfusi secara intrakardial menggunakan $\mathrm{NaCl}$ fisiologis. Jarum suntik dari pompa perfusi dimasukkan ke dalam ventrikel kiri. Setelah jantung membesar karena terisi larutan pre-rinse, atrium kanan dibuka dengan cara digunting sehingga larutan keluar dari jantung.Larutan perfusi diganti dengan larutan paraformaldehid $4 \%$ sebagai larutan fiksatif. Setelah proses perfusi selesai, organ reproduksi, rektum, anus, kelenjar anal diambil, kemudian dilakukan pengamatan makroanatomi meliputi pengukuran, penimbangan. Sampel kelenjar anal difiksasi dalam larutan paraformaldehid $4 \%$ selama $7 \times 24$ jam, kemudian dipindahkan ke dalam larutan alkohol $70 \%$ sebagai stopping point.

Pengamatan secara makroskopis meliputi pengamatan morfologi, pengukuran dan penimbangan. 
Pengamatan secara mikroskopis dilakukan dengan pembuatan preparat histologi. Sampel organ didalam blok parafin dipotong menggunakan mikrotom rotary. Sayatan diletakkan pada kaca objek kemudian disimpan dalam inkubator selama 24 jam dengan suhu $56^{\circ} \mathrm{C}$. Proses selanjutnya pewarnaan $\mathrm{HE}$ merupakan pewarnaan untuk pengamatan struktur histologis umum jaringan.

Pewarnaan di awali dengan proses deparafinisasi dan rehidrasi preparat di larutan xylol, alkohol, air keran dan aquades. Kemudian dilanjutkan dengan pewarnaan hematoksilin selama 1-2 menit dan dicek di bawah mikroskop kadar warnanya. Preparat kemudian direndam dalam air keran selama 10 menit agar biru hematoxylin lebih kuat. Setelah itu preparat di tetesi dengan larutan eosin selama lebih kurang 2 menit. Preparat selanjutnya didehidrasi di larutan alkohol dan di clearing dalam xylol.

Tahap selanjutnya preparat di mounting dengan Entellan ${ }^{\circledR}$. Hasil dari setiap pengamatan makroskopis difoto dan dianalisis secara deskriptif. Pengamatan secara mikroskopis dilakukan dengan pengambilan foto menggunakan mikroskop cahaya dilengkapi dengan alat fotografi kemudian dianalisis secara deskriptif. Hasil analisis diharapkan dapat memberikan gambaran morfologi kelenjar anal musang luak jantan.

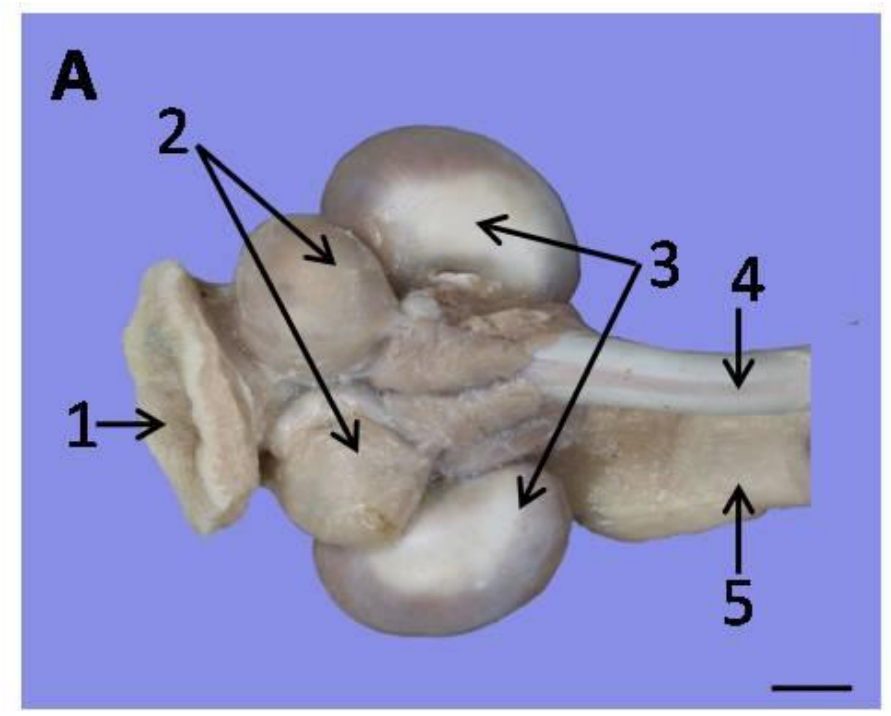

\section{HASIL PENELITIAN}

Musang luak jantan memiliki sepasang kelenjar anal berbentuk kantung bulat menyerupai bola yang terletak dibagian ventrolateral anus (Gambar 1A). Dinding kantung anal tipis terdiri dari jaringan otot skelet dan jaringan ikat. Morfologi kelenjar anal disajikan pada Tabel 1. Kelenjar anal memiliki diameter $1,4 \mathrm{~cm}$ (kanan) dan 1,3cm (kiri), serta bobot 0,86g (kanan) dan 0,69 g (kiri). Masing-masing kelenjar anal memiliki saluran eksretorius yang bermuara di kanal anal yang terletak di dorsolateral anus (Gambar 1B).

Daerah kanal anal musang luak terbagi atas tiga daerah yaitu zona kutaneus, zona intermediate dan zona kolumnar. Posisi kelenjar anal musang luak berada di sekitar zona kutaneus dan zona intermediate. Posisi saluran eksretorius dari kelenjar anal terdapat pada zona kutaneus anus (Gambar 2). Pengamatan makroskopis kelenjar anal terlihat saluran eksretorius dan beberapa tonjolan-tonjolan di dalam permukaan dinding kelenjar anal (Gambar 3). Pengamatan mikroskopis menunjukkan bahwa kelenjar anal musang luak tersusun atas kelenjar sebaceous dan kelenjar keringat apokrin (Gambar 4). Kelenjar sebaceous di selaputi oleh jaringan ikat yang masuk ke dalam kelenjar sehingga membentu lobuslobus. Satu lobus terdiri dari beberapa sel asinar.

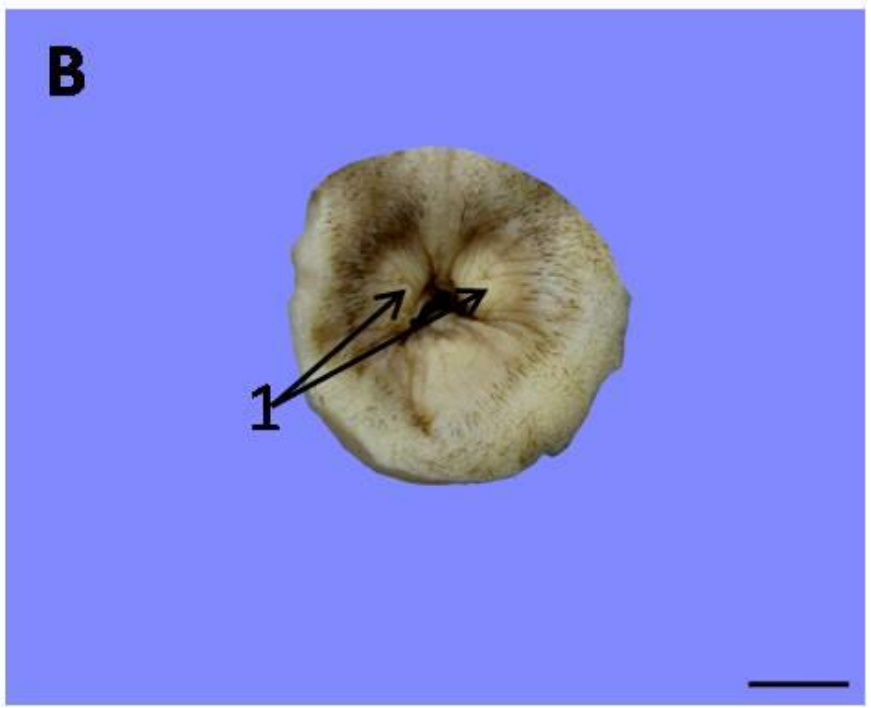

Gambar 1 Gambaran makroskopis regio anorektal musang luak ( $P$. Hermaphroditus) jantan tampak ventral (A): 1. Anus, 2. Kelenjar anal, 3. Kelenjar vesikula seminalis, 4. Penis. Gambaran anus musang luak jantan (B): 1. Saluran eksretorius. Skala $=1 \mathrm{~cm}$. 
Tabel 1 Morfometri organ kelenjar anal musang luak (Paradoxurus hermaphroditus)

\begin{tabular}{|c|c|c|}
\hline \multirow[t]{2}{*}{ Kelenjar Anal } & \multicolumn{2}{|c|}{ Parameter Pengukuran } \\
\hline & Diameter/lebar $(\mathrm{cm})$ & Bobot (g) \\
\hline \multicolumn{3}{|l|}{ Jantan } \\
\hline Sinistra & 1,4 & 0,86 \\
\hline Dextra & 1,3 & 0,69 \\
\hline Rataan & 1,35 & 0,75 \\
\hline
\end{tabular}

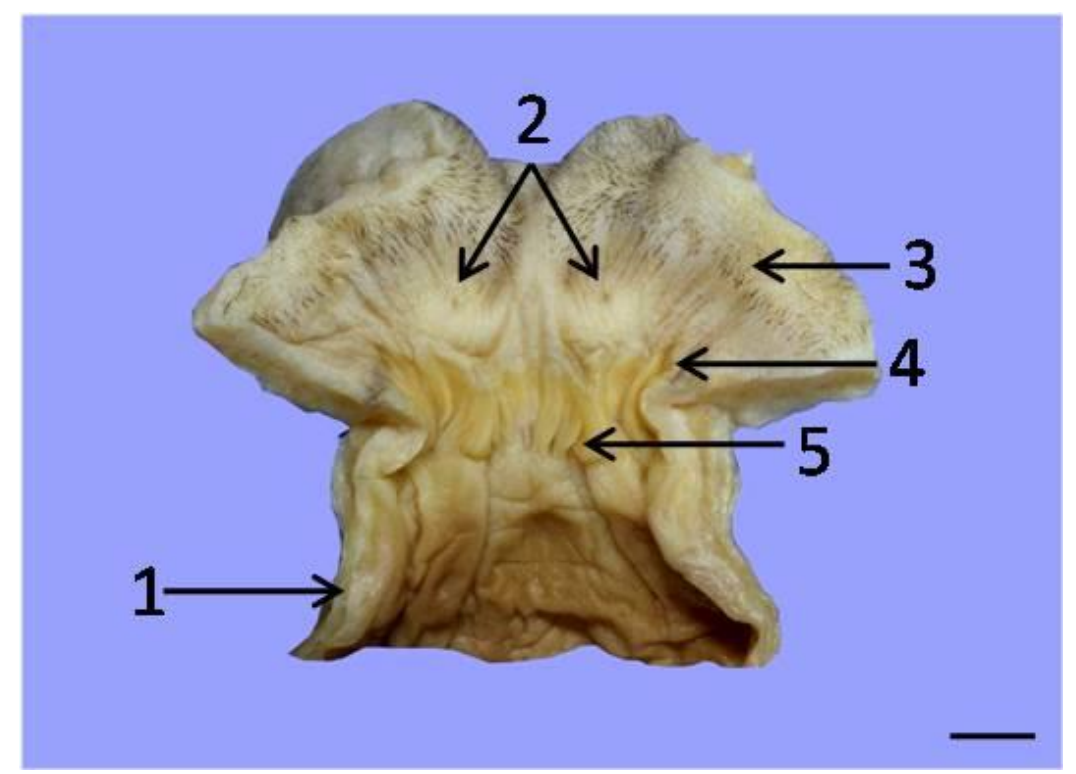

Gambar 2 Gambaran makroanatomi daerah anal kanal dan rektum musang luak (P. Hermaphroditus) jantan tampak dorsal: 1. Rektum, 2. Saluran eksretorius sekretori, 3. Zona kutaneus, 4. Zona intermediate, 5 . Zona kolumnar. Skala $=1 \mathrm{~cm}$

Sel-sel asinar kelenjar anal dibedakan berdasarkan tingkat kematangan yaitu sel asinar muda, sel asinar muda yang matang dan sel asinar matang (Gambar 5). Sel asinar muda ditemukan disekeliling pinggiran lobus, aktif bermitosis, memiliki inti sel yang besar. Sel asinar yang muda yang matang dan sitoplasma mulai berubah menjadi lemak dan sel ini berada di tengah lobus kelenjar. Kelenjar keringat apokrin berada di sepanjang dinding kantung anal dengan kelenjar sebaceous diantaranya. Jumlah kelenjar keringat apokrin lebih banyak daripada kelenjar sebaceous tetapi ukuran kelenjar sebaceous jauh lebih besar dibandingkan kelenjar keringat apokrin (Gambar 5).

Tubulus kelenjar keringat apokrin disusun oleh epitel kolumnar atau kubus selapis dengan bentuk dan ukuran yang bervariasi. Ukuran kelenjar sebaceous lebih besar dibandingkan kelenjar keringat apokrin (Gambar 5). Panjang kelenjar sebaceous sekitar $500 \mu \mathrm{m}-1200 \mu \mathrm{m}$, lebar $300 \mu \mathrm{m}-800 \mu \mathrm{m}$, kelenjar keringat apokrin panjang sekitar $5 \mu \mathrm{m}-50 \mu \mathrm{m}$, lebar $3 \mu \mathrm{m}$ sampai $10 \mu \mathrm{m}$. Musang luak memiliki tiga daerah anal kanal yaitu zona kolumnaris ani, zona intermedia dan zona kutaneus. Pada zona kolumnaris ani terlihat lipatan longitudinal dan merupakan perbatasan dengan rektum. Zona intermedia ditandai dengan mukosa epitel pipih banyak lapis non keratinisasi (Gambar 7). Zona kutaneus ditandai dengan mukosa epitel pipih banyak lapis berkeratinisasi (Gambar 8).

Pada gambar 7 terlihat posisi kelenjar anal terhadap anal kanal, kelenjar anal berada di zona intermedia dan zona kutaneus anal kanal. Hasil sekreta kelenjar-kelenjar anal terkumpul dalam sebuah kantung anal yang nantinya disalurkan melalui sebuah saluran eksretorius menuju anal kanal (Gambar 6). Struktur histologi saluran kelenjar anal terdiri dari lumen yang dikelilingi oleh epidermis, jaringan ikat, setelah lapisan jaringan terdapat otot skelet sirkuler, jaringan ikat, dan epidermis sebagai lapisan terluar saluran eksretorius. 


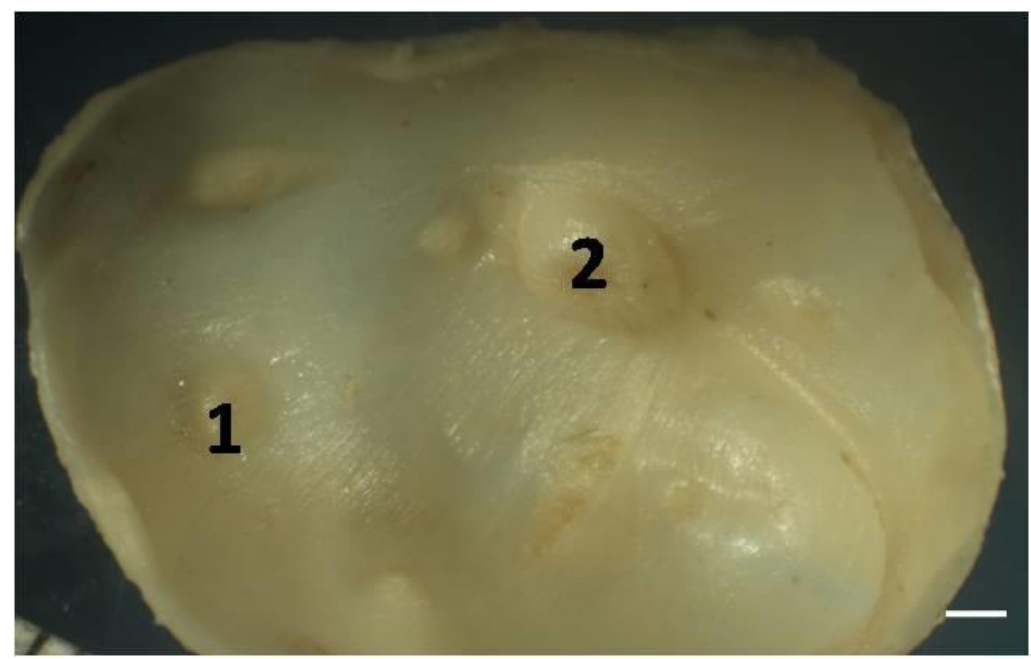

Gambar 3 Dinding bagian dalam kelenjar anal musang luak (P. Hermaphroditus) jantan: $1 . \quad$ Kelenjar sebaceous, 2. Saluran eksretorius. Skala $=2 \mathrm{~mm}$

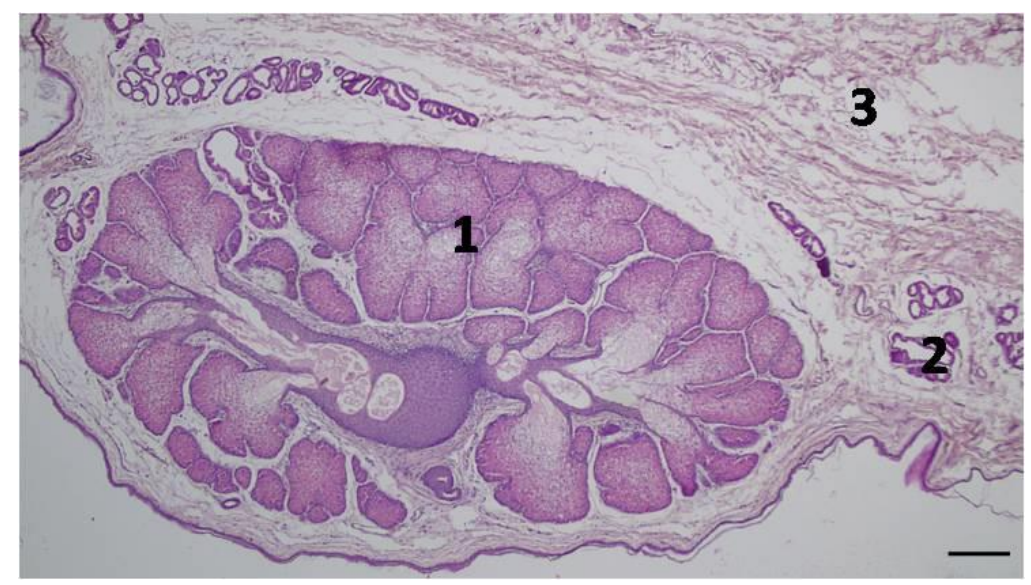

Gambar 4 Gambaran mikroanatomi kelenjar anal musang luak jantan (A): 1. Kelenjar sebaceus, 2. Kelenjar keringat apokrin, 3. Jaringan ikat. Skala $=100 \mu \mathrm{m}$

\section{PEMBAHASAN}

Kelenjar anal musang luak berbentuk kantung dibagian ventrolateral anus, hal ini umum ditemukan pada hewan karnivora yaitu anjing, kucing, sigung dan harimau. Bentuk kelenjar anal pada hewan kucing seperti kantung menyerupai buah kemiri (Maheret al., 2015), harimau memiliki bentuk kantung seperti buah kenari (Hashimotoet al., 1961), otter (Lutra lutra) memiliki bentuk kantung bulat oval (Gormanet al., 1978). Kelenjar anal berbentuk kantung ini menjadi tempat penyimpanan sementara hasil sekreta yang kemudian dieksresikan melalui saluran pendek menuju anal kanal.

Posisi saluran eksretorius musang luak berada di dorsolateral zona kutaneus anal kanal, berbeda dengan saluran eksretorius pada hewan anjing dan kucing yang terletak ventrolateral zona kutaneus anal kanal. Perbedaan posisi ini kemungkinan ber- kaitan erat dengan perilaku hewan tersebut mendepositkan hasil sekreta dari kelenjar anal. Posisi saluran eksretorius musang luak dibagian dorsoventral mendepositkan sekretanya dengan cara menggesek, musang luak jongkok dan membengkokkan keempat kakinya dan mendorong bagian dorsal anus lebih tepatnya posisi saluran ekstretorius dengan bergerak meluncur mengarah kedepan. Terlihat sekreta berwarna kuning kecoklatan memanjang di tempat-tempat yang digesek.

Rohnoz\&Rohnoz(2003) menyatakan perilaku musang luak mensekresikan sekreta kelenjar anal dengan cara menggesekkan daerah sekitar anus. Musang luak lebih memilih menggesek pada benda menonjol seperti akar, cabang pohon yang besar yang berada diatas tanah yang memiliki permukaan yang datar memungkinkan musang meninggalkan sekresi kelenjar anal. Biasanya musang akan meninggalkan sekreta ini ditempat yang permanen 


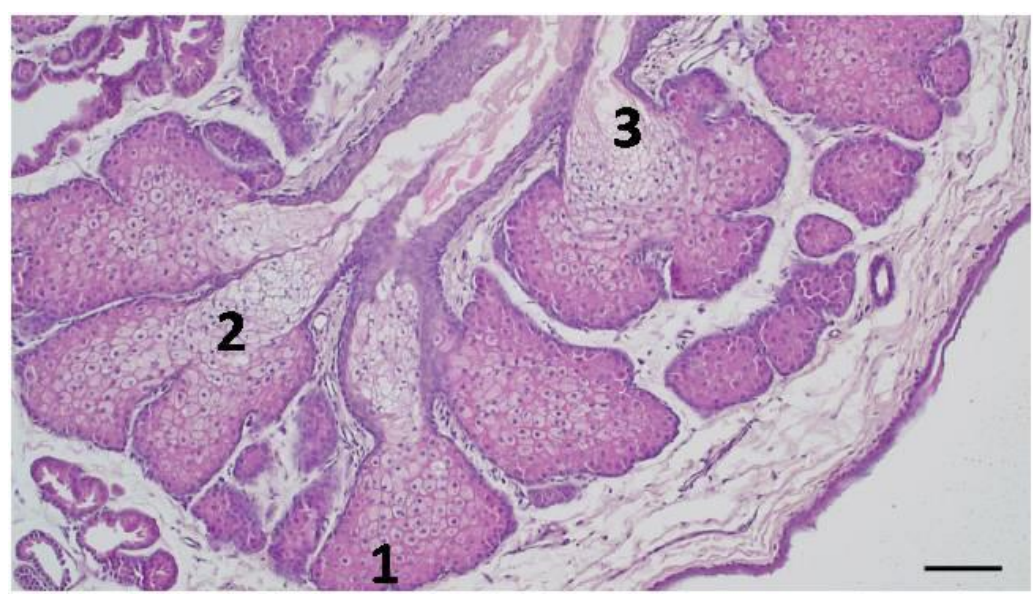

Gambar 5 Lobus-lobus kelenjar sebaceous musang luak (P. Hermaphroditus) jantan (B ): 1. Sel asinar muda, 2. Asinar muda yang matang, 3. Asinar matang. Skala $=50 \mu \mathrm{m}$

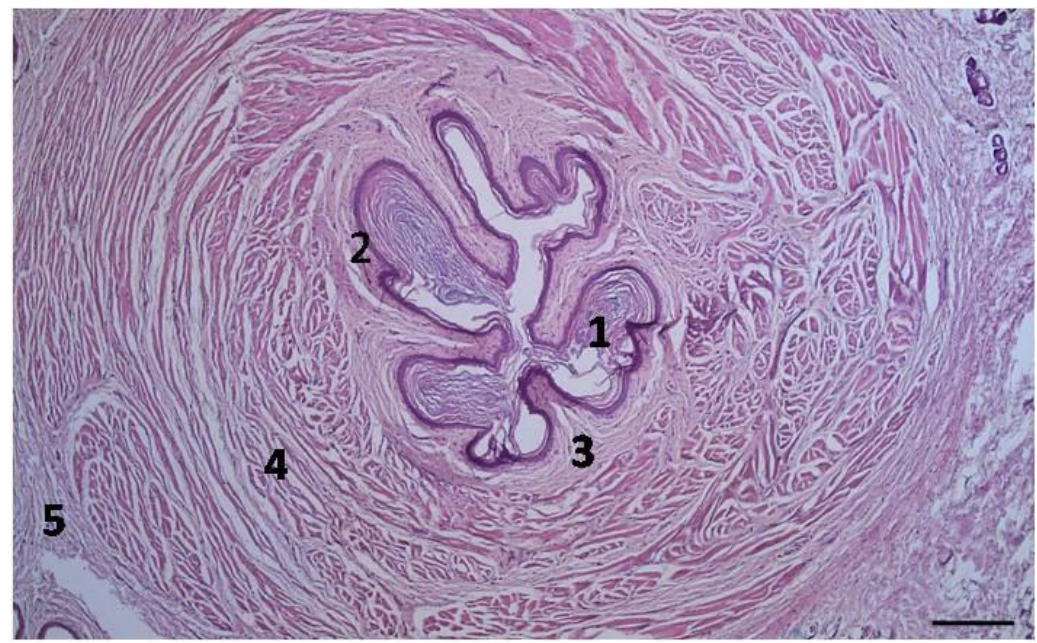

Gambar 6 Gambaran histologis saluran eksretorius kelenjar anal musang luak (P. Hermaphroditus) jantan : 1. Stratum korneum, 2. Stratum granulosum dan stratum basale, 3. Jaringan ikat 4. Otot skelet sirkuler, 5. Jaringan ikat. Skala $=100 \mu \mathrm{m}$

dan mudah terlihat. Kucing mensekresikan sekreta kelenjar anal ini bersamaan dengan feces oleh kontraksi otot. Anjing mensekresikan kelenjar anal ini saat defekasi, pada anjing liar akan menggosokkan bagian anus ke permukaan vertikal sebagai aroma penanda (Maher et al., 2015).

Musang luak memiliki tiga daerah anal kanal yaitu zona kolumnaris ani, zona intermedia, zona kutaneus. Pada zona kolumnaris ani terlihat lipatan longitudinal dan merupakan perbatasan dengan rektum. Zona intermedia ditandai dengan mukosa epitel pipih banyak lapis non keratinisasi. Pada zona ini banyak ditemukan kelenjar keringat apokrin berukuran besar. Ukuran kelenjar keringat apokrin yang terdapat pada zona intermedia jauh lebih besar dibandingkan dengan kelenjar keringat apokrin yang terdapat di kelenjar anal dan terdistribusi rata hampir di semua zona intermedia (Gambar 7). Zona kutaneous ditandai dengan mukosa epitel pipih banyak lapis berkeratinisasi. Pada zona ini banyak ditemukan kelenjar sebaceous berukuran besar sama seperti kelenjar sebaceous yang terdapat di kelenjar anal dan kelenjar keringat apokrin berukuran kecil diantaranya. Kelenjar sebaceous yang terdapat pada zona kutaneus terdistribusi merata diseluruh area zona (Gambar 8). Posisi kelenjar anal musang luak berada disekitar zona intermedia dan zona kutanea anal kanal. Pada babi dan karnivora, anal kanal dapat dibedakan menjadi tiga daerah yaitu zona kolumnaris ani, zona intermedia dan zona kutanea (Dellmann \& Brown, 1992).

Dalam satu kantung anal terdapat beberapa unit kelenjar sebceous berbentuk tonjolan bulat lonjong. Dalam satu kantung tersebut terdapat satu saluran ekstretorius berupa tonjolan bulat yang merupakan invaginasi dari kulit membentuk saluran dengan lumennya. Saluran ekstretorius ini lebih dominan dike- 


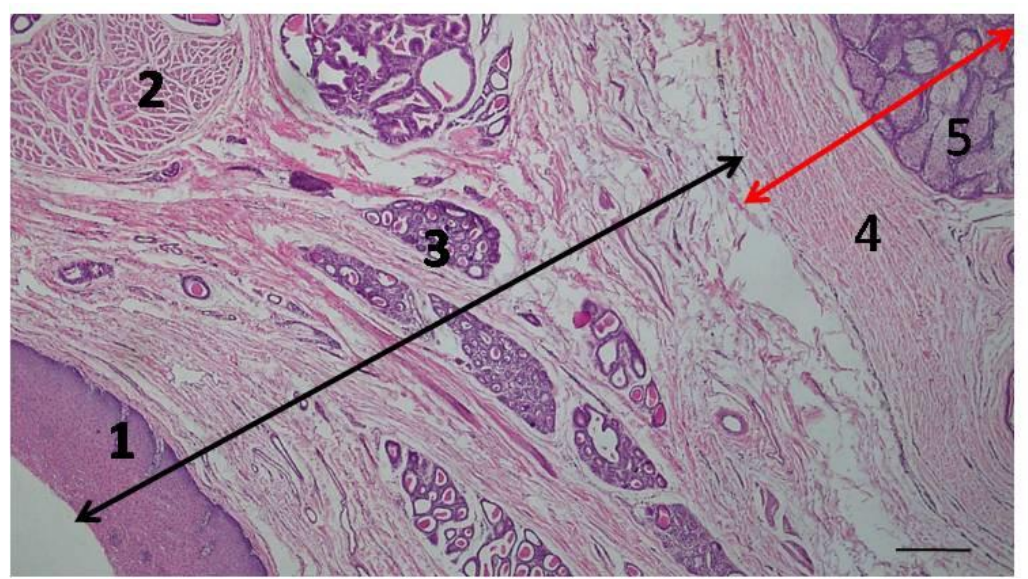

Gambar 7 Gambaran mikroskopis anal kanal zona intermediate $(\longleftrightarrow)$ dan kelenjar anal $(\longleftrightarrow)$ musang luak jantan: 1. Epithelium pipih banyak lapis non keratinisasi 2. Musculus sphincter ani 3. Kelenjar keringat apokrin, 4. Jaringan ikat, 5. Kelenjar sebaceus. Skala $=100 \mu \mathrm{m}$

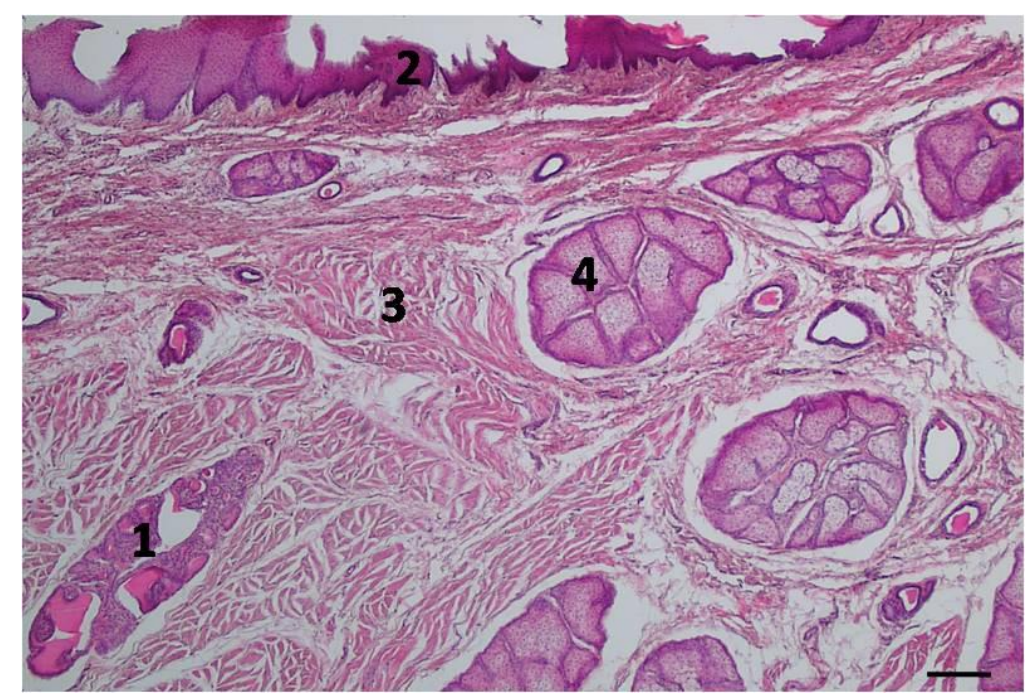

Gambar 8 Gambaran mikroskopis anal kanal zona kutaneus musang ( $P$. Hermaphroditus) luak jantan: 1. Kelenjar keringat apokrin, 2. Epithel pipih banyak lapis berkeratinisasi, 3. musculus sphincter ani bagian internal, 4 . Kelenjar sebaceous. Skala $=100 \mu \mathrm{m}$

lingi oleh otot sirkuler, di duga kontraksi dari otot sirkuler ini membantu pengeluaran sekreta dari kelenjar anal.

Sekreta kelenjar anal pada musang luak menpunyai konsistensi seperti pasta,berwarna kuning kecoklatan dan berlemak. Pada anjing sekreta mempunyai konsistensi yang dari cairan, agak kental sampai berbentuk pasta, dengan warna coklat atau coklat keabu-abuan (Pappalardo et al., 2002). Sedangkan sekreta pada kucing berwarna putih, kuning muda oranye dengan konsistensi kental, berlemak sampai cair (Frankelet al.,2008). Perbedaan konsistensi sekreta ini kemungkinan disebabkan oleh perbedaan distribusi kelenjar sebaceous dan kelenjar keringat apokrin yang terdapat pada kelenjar anal.
Musang luak memiliki kelenjar keringat apokrin dan kelenjar sebacoeus pada dinding kantung anal sama seperti kucing pada kantung analnya berkembang baik kelenjar keringat apokrin dan kelenjar sebaceous. Komposisi kelenjar sebaceous lebih banyak terdistribusi pada hewan musang luak begitu juga pada kucing (Maher et al., 2015). Hashimoto et al. (1963) dalam studi kelenjar anal pada harimau juga menemukan kelenjar keringat apokrin terdistribusi di dinding kantung anal bersama dengan kumpulan kelenjar sebaceus yang lebih dominan.

Pada anjing kelenjar yang dapat ditemukan pada kantung anal hanya berupa kelenjar keringat apokrin yang lebih dominan dan kelenjar sebaceous ditemukan di dinding bagian saluran eksretorius. Kelenjar sebaceous memiliki sel asinar yang 
berlobus-lobus. Sel asinar muda ditemukan disekeliling pinggiran lobus, aktif bermitosis, memiliki inti sel yang besar. Sel sinar yang muda yang matang dan sitoplasma mulai berubah menjadi lemak dan sel ini berada di tengah lobus kelenjar. Sel asinar matang memiliki banyak lemak dan mulai hancur beserta dengan inti selnya. Sekresi kelenjar sebaceus ini berupa sebum mengandung lemak dan sel debris.Sebum ini memiliki fungsi sebagai bakterostatik dan sebagai feromon (Henriksonet al., 1997). Kelenjar sebaceous memiliki pola sekresi holokrin, sekresi dibebaskan diikuti dengan kehancuran dan kematian sel-sel. Proses ini memerlukan pergantian sel-sel yang konstan dari sel-sel basal yang aktif. Saluran pendek untuk mengeluarkan sekreta kelenjar sebaceous biasanya menuju folikel rambut atau langsung ke permukaan kulit.

Kelenjar keringat terdiri dari dua tipe yaitu kelenjar keringat merokrin dan kelenjar keringat apokrin. Penamaan tersebut dulunya sesuai dengan pola sekresi kelenjar, tetapi penelitian terakhir menyebutkan kelenjar keringat apokrin memiliki pola sekresi merokrin yaitu mensekresikan substansi sementara sel-sel tetap utuh(Bacha\&Bacha, 2012). Sekreta kelenjar keringat apokrin umumnya bersifat kental berfungsi sebagai feromon pada beberapa hewan mamalia (Henrikson et al., 1997).

Kelenjar sebaceous dan kelenjar keringat apokrin pada kelenjar anal hewan jantan dan betina musang luak diduga erat hubungannya dengan komunikasi reproduksi. Musang luak betina mengeluarkan aroma pandan lebih wangi pada saat estrus dan lebih memilih musang jantan dengan aroma pandan yang lebih kuat. Selain sebagai komunikasi reproduksi musang luak jantan mengeluarkan sekreta ini sebagai media komunikasi antara spesies, sesama spesies, dan antara jenis kelamin.

\section{UCAPAN TERIMA KASIH}

Ucapan terima kasih disampaikan kepada Direktorat Jenderal Pendidikan Tinggi Kementerian Riset Teknologi dan Pendidikan Tinggi atas pemberian beasiswa dan Sekolah Pascasarjana IPB atas kesempatan menempuh pendidikan S2 di IPB

"Penulis menyatakan tidak ada konflik kepentingan dengan pihak-pihak yang terkait dalam penelitian ini"

\section{DAFTAR PUSTAKA}

Apriliani F. 2012. Morfologi organ reproduksi betina musang luak (Paradoxurus hermaphroditus). Skripsi. Bogor (ID): Institut Pertanian Bogor.

Bacha WJ, Bacha LM. 2012. Color Atlas of Veterinary Histology Third Edition. John Wiley and Son.

Baker N, Kelvin L. 2008. Wild Animals of Singapore: A Photographic Guide toMammals, Reptiles, Amphibians, and Freshwater Fishes. Singapura: Vertebrate Study Group, Nature Society.

Dellmann HD, Brown EM. 1992. Buku Teks Histologi Veteriner. Penerbit Universitas Indonesia, Jakarta.

Gorman ML, Jenkins D, Harper RJ. 1978. The anal scent sacs of the otter (Lutra lutra). Journal Zoology. London186: 463-474.

Grzimek's B, Schlager N, Olen dorf D. 2004. Grzimek's Animal Life Encyclopedia. Detroit: Gale.

Hashimoto Y, Eguchi Y, Arakawa A. 1963. Histological observation on the anal sac and its glands of a tiger. Journal Veteriner Science 25: 29-32.

Henrikson RC, Kaye GI, Mazurkiewicz JE. 1997. Histology. Lippincott Williams and Wilkins, USA.

Hong-Fa X, Bing Z, He-Ling Sheng. 1995. A study of the behavior of small civet (Viverricula indica) during the estrus period. Zoological Research 16 (4): 359-364.

Frankel JL, Scott DW, Erb HN. 2008. Gross and cytological characteristic of normal Feline anal sac secretion. Journal of Feline Medicine and Surgery 10:319-323.

Kosim I. 2015. Gambaran Anatomi dan Histologi Lidah Musang Luak (Paradoxurus hermaphroditus). Skripsi. Bogor (ID): Institut Pertanian Bogor.

Maher MA, El -Sakhway, Hussein MA, Shaker NA. 2015. Morphological studies on the anal canal of adult male cat (Felis domestica). International Journal of Advanced Research in Biological Sciences 2: 195-205.

Nijman V, Spaan D, Rode Margono EJ, Roberts PD, Wirdateti, Nekaris KAI. 2014. Trade in common palm civet Paradoxurus hermaphroditus in Javan and Balinese markets, Indonesia. Small Carnivore Conservation 51:11-17.

Panggabean E. 2011. Mengeruk Untung dari Bisnis Kopi Luak. Jakarta: AgroMedia Pustaka. 
Pappalardo E, Martino PA, Noli C. 2002. Macroscopic, cytological and bacteriological evaluation of anal sac content in normal dogs and in dogs with selected dermatological disease. Veterinary Dermatology 13: 315-322.

Putra SM. 2012. Morfologi Organ Reproduksi Musang Luak Jantan (Paradoxurus hermaphroditus). Skripsi. Bogor (ID): Institut Pertanian Bogor.
Rozhnov VV, Rozhnov YV. 2003. Roles of different types of excretions in mediated communication by scent marks of the common palm civet, Paradoxurus hermaphroditus. Biology Bulletin 30: 584-590.Suyanto A. 2002. Mammalia di Taman Nasional di Gunung Halimun Jawa Barat. Puslit Biologi-LIPI. Bogor.

Tsukise A, Wilfred M, Daisuke N, Kaori K, Junpei K, Osamu F. 2000. Lectin histochemistry of the canine anal glands. Annals of Anatomy 182:151-159. 